\title{
National River Linking Project of India
}

Naveen M. Joshi

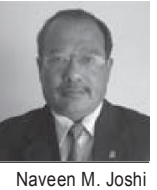

Abstract: India plans to transfer water from the water surplus region of the north-east to the water scarce regions of western and southern India. The plan is called the National River Linking Project (NRLP). Sixteen links in the Himalayan region and 14 links in the Peninsular region are proposed that will transfer annually about 174 Billion $\mathrm{m}^{3}\left(\mathrm{Bm}^{3}\right)$ of water through a canal network of $14,900 \mathrm{~km}$. It will involve connecting 37 rivers and construction of dams/storages in 3,000 places. It is estimated to cost US $\$ 120$ Billion (in 2000 price). The projected benefits are additional irrigation to 34 million hectares of land, generation of $34,000 \mathrm{MW}$ of electricity, reduction of floods, and social upliftment.

Many prominent experts and personalities have criticized the project claiming that it will be a financial, social and environmental disaster. Both the proponents and opponents think that India will be doomed depending on whether the NRLP is implemented or not (Amarsinghe 2009). The International Water Management Institute (IWMI) in collaboration with the Challenge Program for Water \& Food (CPWF) undertook a three year Strategic Analysis of the NRLP to evaluate the NRLP concept with a detailed analysis.

This paper is a general description of the NRLP, and it summarizes the findings of the Strategic Analysis of this Project undertaken by IWMI-CPWF. Further, it explores the possible consequences to India's neighbors in general and Nepal in particular.

Key words: River Linking Project, Himalayan link, peninsular link, inter basin water transfer, Strategic Analysis, India

\section{Background}

Tndia is planning a very ambitious and gigantic water transfer project called the National River Linking Project (NRLP) from the surplus region in the north-east with major rivers of the South Asian region i.e the Ganges and the Brahmaputra, to the water scarce areas of western and southern India. It will be in two parts- one is the Himalayan part involving 16 links and the other is the peninsular part involving 14 links. It will connect 37 rivers and will have 3,000 storages. In total $174 \mathrm{Bm}^{3}$ of water will be transferred through a network of $14,900 \mathrm{~km}$ of canals. It claims to be the largest infrastructure project in the world. It will cost US\$ 120 Billion (at 2000 price) and is expected to provide enormous benefit with additional irrigation capacity of 34 million hectares ( $\mathrm{MHa}$ ) (24 $\mathrm{MHa}$ surface + $10 \mathrm{MHa}$ ground water) of agricultural land, generation of 34,000 MW of hydropower, decreasing flooding in the eastern region etc. About 1.48 million people will be displaced by the proposed Project. The verdict of the Supreme Court of India which directed the Government of India to go ahead with the project in a time bound manner underscores the legal backing for the project.

Critics complain that the Indian Government has not undertaken sufficient detailed analyses for alternatives; whereas, the Indian Government reiterates that considering the magnitude of the crisis, the NRLP is the only option. Both the opponents and proponents of the enterprise think that India will be doomed depending on whether the NRLP is implemented or not. There are many opinions and assertions about the project; but has little analytical rigor (Amarsinghe 2009).

India faces severe flooding in several places and at the same time draught in other places. The nonhomogeneity in the available water resources, both spatial and temporal, had given the impetus to undertake large scale water resources development in India. To boost the agricultural production, improve domestic water supply, and address the energy crisis as well as to ameliorate the socio-economic conditions in the water scarce regions, large inter-basin transfers have been suggested.

Previously, this project was scheduled to be completed by 2016 . Now the completion date may be within 2050 .

There is no debate about the requirement of additional water in coming decades due to increasing population and decreasing river flows aggravated by the climate change phenomenon. Yet, the critics claim that the project is planned without considering alternatives, and the said project will be an economic, social and environmental disaster.

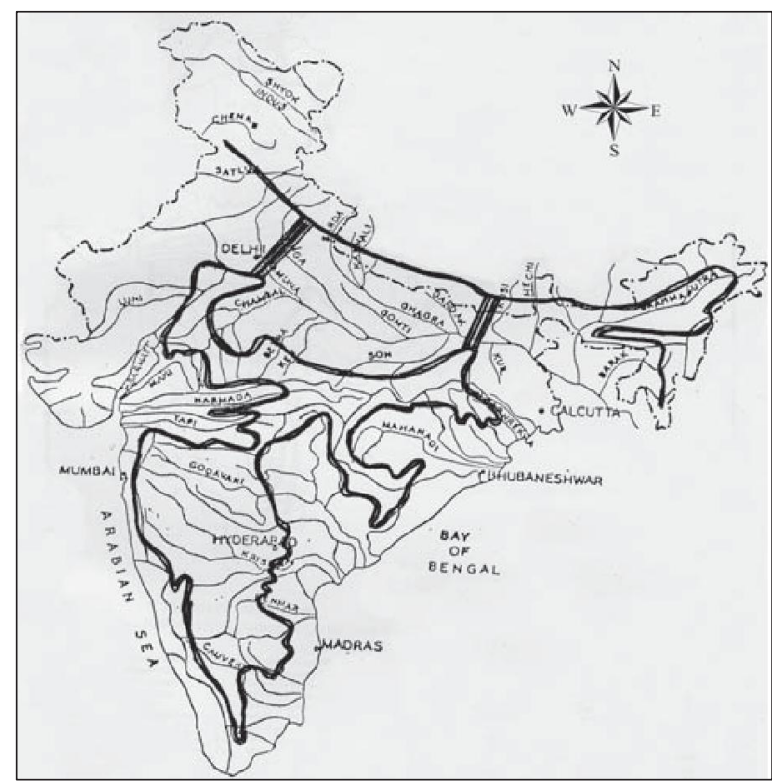

Capt. D.J.Dastur's Proposal 


\section{The Project History}

In the nineteenth century, Sir Arthur Cotton had made a navigational plan for India from Assam to Mumbai primarily for the transportation of goods. Later in 1977, Captain D. J. Dastur had submitted a proposal to construct a high level canal to collect water from the rivers like Ravi, Sutlej, Yamuna, Ganga and Brahmaputra known as the Himalayan canal for transferring the harnessed waters down through the southern garland canals. The Himalayan canal would be about 2,400 $\mathrm{km}$ long and aligned along the southern slopes of the Himalayas and extending beyond the Brahmaputra towards the south by another canal $1,770 \mathrm{~km}$ long. The Central and Southern Garland canal would be around 9,332 km. Captain Dastur's proposal would cost Indian Rupees IRs. 120 trillion.

Another proposal, the National Water Grid, comprising the following components to interlink the major rivers was made by Dr. K. L. Rao in 1979. The National Water Grid comprised the following links:

- Ganga-Cauvery link connecting the Ganga with the Cauvery passing through the basins of Sone, Narmada, Tapi, Godavari, Krishna and Pennar,

- Brahmaputra Ganga link,

- Canal from Narmada to Gujarat, Western Rajasthan and Maharashtra, and

- Links from the rivers of the Western Ghats to the East.

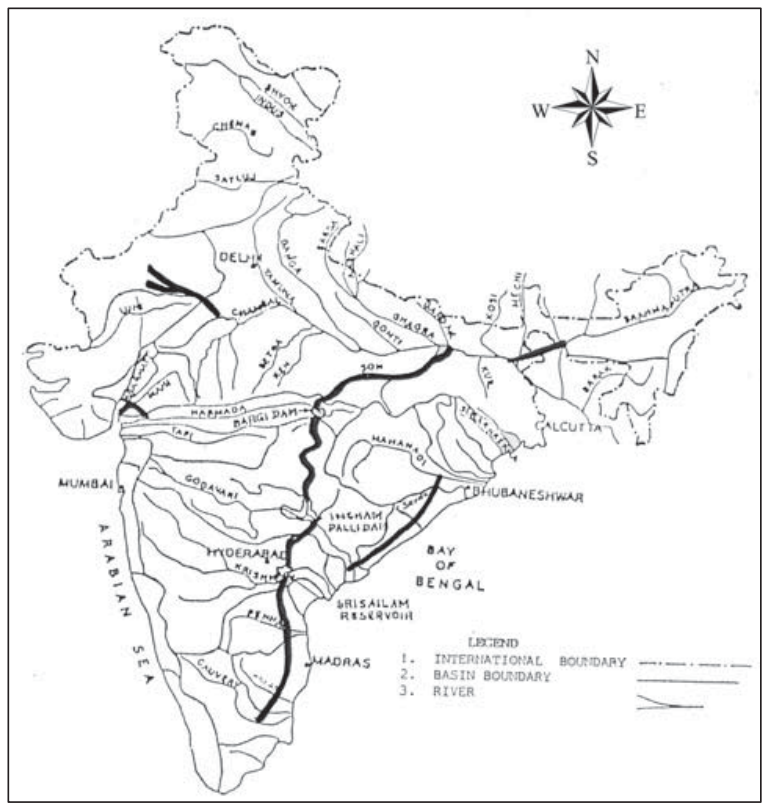

K. L. Rao's Proposal

\section{National Water Development Agency Plan}

The Central Water Commission evaluated the proposal as a technically feasible but costing a huge amount. The proposal would also need a large block of power for lifting water in the Ganga-Cauvery section. As an alternative to the above mentioned two proposals, the National Perspectives Plans developed by the National Water Development Agency (NWDA) made a separate proposal for the inter-basin transfers. This proposal comprises two components, viz.

1. Himalayan Rivers Development and

2. Peninsular Rivers Development.

\section{Components of the Proposed NRLP}

The Himalayan component has been proposed to transfer $33 \mathrm{Bm}^{3}$ of water through 16 river links. It has two sub components linking the (Amarsinghe 2009):

1. Ganga and Brahmaputra to the Mahanadi Basin, and

2. Eastern Ganges tributaries and Chambal, Sabarmati river basins.

The Peninsular component has been proposed to transfer $141 \mathrm{Bm}^{3}$ water through 14 river links. It has four sub components linking the:

- Mahanadi and Godavari basins to the Krishna, Cauvery and Vaigai rivers;

- West flowing rivers south of Tapi to north of Mumbai;

- Ken river to the Betuwa river and Parbati, Kalisindh rivers to the Chambal rivers; and

- Some west flowing rivers to the eastern river.

It is very strange that only $33 \mathrm{Bm}^{3}$ of water is proposed to be transfered in Himalayan Component having 1154.1 $\mathrm{Bm}^{3}$ of annual flows of Gangas and Brahmaputra; whereas $141 \mathrm{Bm}^{3}$ is proposed to be transferred in peninsular component having $177.4 \mathrm{Bm}^{3}$ annual flows of Godabari and Mahanadi

\section{Project Benefits}

The NRLP envisages to:

- provide additional irrigation to 34 million ha of cropped area and water supply to domestic and industrial sectors;

- add $34 \mathrm{GW}$ of hydropower potential to the national grids;

- mitigate floods in the eastern India; and

- facilitate various other economic activities such as internal navigation, fisheries, groundwater recharge, environmental flows of water-scarce rivers.

The project cost of the NRLP would be more than US\$ 120 Billion (in 2000 prices) of which the:

- Himalayan component cost would be US\$ 23 billion;

- peninsular component cost would be US\$40 Billion; and

- hydropower component cost would be US\$ 58 Billion.

The NRLP, when completed, will increase India's utilizable water resources by $25 \%$, and reduce inequality of water resources endowments in different regions (Amarsinghe 2009).

\section{Himalayan Components}

The Himalayan Rivers' component envisages the construction of storages on the main Ganga, and the Brahmaputra as well in principal tributaries both in India and Nepal so as to conserve the monsoon flows and acrue benefits from, hydropower generation, irrigation and flood control. An interlinking canal system will 


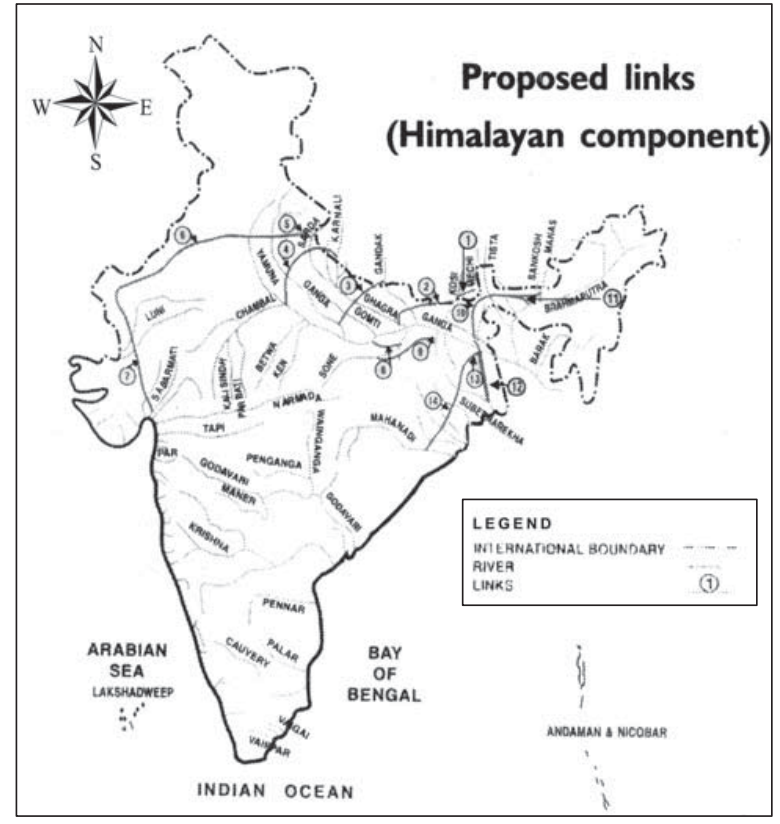

be provided to transfer the surplus flows of the Kosi, Gandak and Ghagra to the west end of the Ganga and Yamuna to the Sutlej and Beas. Part supplies of the Beas and Ravi would be available for further transfer to the south in the drought prone areas of Haryana, Rajasthan and Gujarat. The Brahmaputra will be linked to the Ganga for augmenting the dry season flows of the Ganga in the downstream reaches.

\section{Peninsular Component}

The Peninsular Rivers' Development component is in four parts. The first part is the Mahanadi-Godavari-KrishnaPennar-Cauvery link. It was considered that, among the peninsular rivers, the Mahanadi and Godavari have sizable surpluses after meeting the projected needs of the States within these basins. It was therefore, proposed to divert about $61 \mathrm{Bm}^{3}$ of surplus flows of the Mahanadi to and the Godavari system in eight links which will utlise 18.3 $\mathrm{Bm}^{3}$ in en route that will help irrigate 2.9 Mha of culturable land and will supply $3 \mathrm{Bm}^{3}$ of domestic and industrial water. This would enable irrigation in the drought prone areas of Maharashtra, Karnataka, Andhra Pradesh and Tamil Nadu.

The second part consists of diverting surplus water of the west flowing rivers of Kerala and Karnataka to the east of the Western Ghats. The third part envisages to construct storages and to interlink the small rivers flowing along the west coast, north of Mumbai and south of Tapi. This will enable partial release of water from the Tapi and Narmada for extension of irrigation to Saurastra and Kutch areas. It will also enable the provision of extra water to meet the growing needs of the metropolitan area of Mumbai as well as providing irrigation to the coastal area of Maharashtra. The fourth part envisages the interlinking of the Southern tributaries of the Yamuna like the Ken and Chambal in addition to construction of

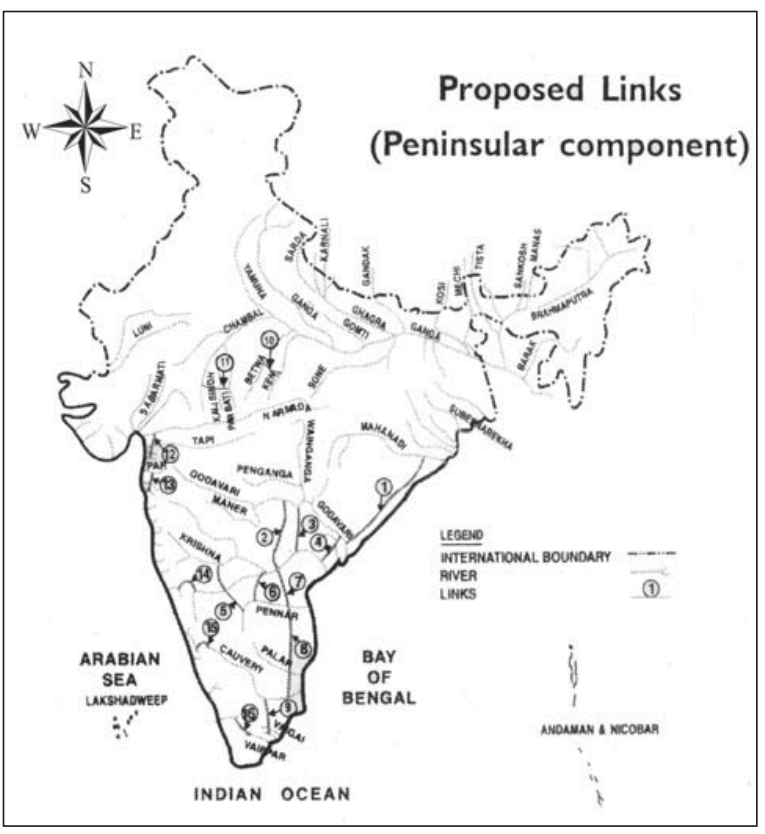

small storages on intermediate tributaries and a dam on the Yamuna at Panchanad. This will provide irrigation in the Ujjain and Indore areas of Madhya Pradesh. It is estimated that the proposal of the Peninsular River Development will enable additional use of water to irrigate 13 Mha in the states of Orissa, Andhra Pradesh, Maharashtra, Karnataka, Tamilnadu and Madhya Pradesh besides generation of power.

\section{Directions from the Supreme Court}

Under the direction of the Supreme Court, a Task Force was established on December 13, 2002 with Mr. Suresh Prabhu as the Chairperson. Further, the Supreme Court on November 10, 2003 asked the Centre Government to give the status report detailing the progress made on the ambitious IRs. 5,60o billion (estimated about 2 decades ago) river networking project to link the major rivers by 2016. Further, the Supreme Court headed by Justice S. H. Kapadia on February 27, 2012 has asked the GOI to go ahead linking the rivers in India in the scheduled time frame.

\section{Strategic Analysis of India's River Linking Project} In 2005, the International Water Management Institute (IWMI) and the Challenge Program on Water and Food (CPWF) started a three year research study on the "Strategic Analysis of India's River Linking Project (SAIRLP)". The primary focus of the IWMI-CPWF project was to provide the public and policy planners with a balanced analysis of the social benefits and costs of the NRLP. The project consisted of research in three phases. Phase-I analyzed India's water future scenarios to 2025/2050 and related issues. Phase-II analyzed how effective a response the NRLP is for meeting India's water future and its social costs and benefits. Phase-III contributed to an alternative water sector perspective 
plan for India as a fallback strategy for the NRLP (Amarsinghe 2009).

This was a vast study conducted by IWMI-CPWF. It involved 15 project partners. This analysis has generated several volumes of reports. The analysis of IWMI-CPWF was timely. This research project attempted to fill the void of analytical rigor in the discourse of the NRLP debate. This study resulted in the publication of five books and a series of related Reports and Proceedings of the workshops.

\section{Summary of Findings of the SAIRLP \\ Phase I:}

- Future water demand is projected to be increased by 22\% and 30\% in 2025 and 2050 respectively;

- Since last two decades ground water has been a major source of meeting the increasing demand for water, and in future also the same trend will continue creating severe ground water over-exploitation;

- The options are: rainwater harvesting, ground water recharge, water saving technologies, water markets to reduce ground water use, carefully crafted virtual water trade;

- Inter basin water transfer will increase ground water recharge; and

- At a time when there will be full impact of climate change, the NRLP will produce great benefits;

During the study, the share of the agriculture sector in the GDP was only $17 \%$ whereas $70 \%$ of the population in the rural areas was engaged in agriculture. Two thirds of the rain fed farm land produces only one third of farm products.

\section{Phase II:}

- Inadequate detailed planning in the proposed links;

- Water surplus availability forecast in a basin needs to be based on the detailed requirement in the basin including downstream riverine requirement. Monthly water availability needs to be considered, otherwise, it will show surpluses.

- The existing cropping pattern is of higher value than the proposed one. Rice, wheat is proposed to be increased; whereas rice planting is decreasing over the years.

- Conflict of interests among the stakeholders across the basin will be more complex than the hydraulic structures. Strong basin organizations will be required.

- Properly designed, disseminated, and implemented rehabilitation and relief packages for the project affected people will be necessary.

- Land acquisition must be handled with care as civil society organizations have been vocal and effective.

\section{Phase III:}

- Improving water productivity,

- Improving rain fed agriculture,

- Water demand management,

- Carefully crafted virtual water trade between states,
- Ground water recharge and water harvesting,

- Replacing long duration crops with short duration crops,

- Growing crops where yields are higher due to climatic advantages, better soil nutrient or lower ET demand,

- Changing the focus and priorities of the Master plan of Ground Water Recharge,

- Improving the quality of irrigation water supply, and

- Improving quality of power supply.

\section{Review of the Irrigation Sector by the SAIRLP}

After 1990, IRs. 1,000 Billion (US\$ 24 Billion at 2006 price) spent on surface irrigation has produced hardly any additional increase in irrigated area. The economic performance of the surface irrigation system is declining. On the other hand, ground water has been extensively used since the last two decades and it continues to grow and reach an unsustainable level. It will be fruitful to plan for the over exploitation of ground water by recharging ground water aquifers by rainwater harvesting. It needs supply augmentation and irrigation demand management. Surface irrigation efficiency is projected to be $60 \%$ from the present $30-40 \%$, which is unrealistic; whereas tubewell irrigation will have a $72 \%$ efficiency. Further, the major exports are from horticulture, dairy products, spices, and most of them are grown in dry land. Fodder or tree crops will increase trading opportunities.

In India two thirds of the farms are irrigated through ground water. Ground water is the source of irrigation in $90 \%$ of the command areas of the proposed GodavariKrishna Link at present. Hence, the economic benefit from additional per cubic meter of proposed water transfer will be low.

The National Commission on Integrated Water Resource Development (NCIWRD)'s assumptions and predictions in respect to the NRLP planning has been proved to be unrealistic by the SAIRLP. In most cases, the situation has already changed. For example, the SAIRLP gave very different views on population growth, share of irrigation by surface irrigation, efficiency of surface irrigation, farm yield, food grains requirement etc.

The study has cited the case of the Sardar Sarovar Project of south India. Its estimated cost was IRs. 68,400 million in 1986/87. Till now IRs. 200,000 million has been spent producing $0.1 \mathrm{MHa}$ of irrigated land out of the 1.8 Mha target, 200 MW of electricity generation out of $1,460 \mathrm{MW}$, and water supplies for 170 towns/cities. The project needs another IRs. 200,000 million and another 10 years for completion.

The SAIRLP has given great emphasis on ground water use, ground water recharge with rain water harvesting, and has questioned the effectiveness of surface irrigation systems.

The revised food grain demand is $380 \mathrm{Mt}$ (reduced from 440 Mt of NCIWRD's estimate) by 2050 up from $200 \mathrm{Mt}$ in 2000. If India's average yield is increased to 4 t/ha (China's present level) even over a 50 year period, 
there will be self sufficiency in food without any farming in additional land.

This (IWMI-CPWF) study has raised questions on what benefits this project will provide after spending such a colossal amount of money. Further, the study questions the investment capability of India, when the Government finds it hard to continue financing even the ongoing projects.

\section{Progress till Date in the NRLP}

The National Water Development Agency (NWDA) was established in 1982 for implementing the NRLP. The NWDA has already completed the Feasibility Study of a) the Ghagara - Yamuna Link, and b) the Sarada -Yamuna Link.

Further, the Bihar Government has completed a DPR in two following links which are approved by the Central Government. They will be part of the NRLP.

$$
\text { - Buri Gandak - Noon-Baya-Ganga }
$$

- Koshi - Mechi

Near the Nepal border, India has already constructed infrastructures to transfer water from the Ghagara, Babai and Rapti rivers.

\section{Consequences of the Proposed Project}

The ambitious project to transfer water from the surplus basin to the deficit basin could definitely be ideal in the sense of irrigating the barren land for more agricultural production, additional energy as well as navigation and other benefits. At the same time, it should also be kept in mind that modifying the behavior or courses of rivers is essentially geomorphic engineering, and naturally involves all the factors of geomorphology. A river is the most active element in a landscape, being the dominant factor shaping the landforms. The effects are erosion and deposition, in a complex pattern along the profile. In the lower reaches, the silt deposition is finer in grain size and the river follows a convoluted meandering course. The course of the river is always a shifting line, but the degree of mobility is more in the downstream reaches.

The entire valley of a river is sculpted by its water and is in a dynamic state. A river is an open system, as it constantly exchanges materials and energy with its environment. The study of a river needs to be taken as a system rather than a single water course. The river, unlike a canal, augments its flow all along its path, by additions from the tributaries and from rain in the lower catchment. The geomorphology is thoroughly stochastic, within a rough deterministic envelope. In one sense, the catchment is the envelope. Rivers are bounded by these domains and shaped by their domains. Breaking the envelope would unleash forces of uncontrolled change, and invite unintended consequences as mentioned below:

- The diversion of river would lessen the silt deposition in the river mouth or coastal area. This would result in erosion of the coastal area. The Akosombo Dam on the Volta River in Ghana has reduced the sediment to the coast, resulting in coastal erosion.

- Salt water intrusion into the land would occur as the river would have reduced discharge into the sea thus affecting the coastal agricultural production as well as the drinking water availability.

- Reduced discharge into the sea would affect the commercial fisheries. Dams and diversions have reduced the discharge of several rivers into the Caspian, Black and Azov Seas by 50 to 70 percent causing a reduction of commercial fisheries by over 90 percent.

- Prediction of surplus water would be a matter of question as the significant changes that are likely to take place in the hydrological flows due to climatic changes and glacial retreat.

- An artificially constructed river channel may not have the regime condition resulting in breaching of the channel. The Kosi River was breached in August 2008 affecting six million people in Nepal and India.

- It is doubtful whether the proposed river linking project is based on the understanding of the overall environment and ecosystem of the rivers?

\section{Reactions from the Critics}

Several experts and representatives from the society have raised their voices and concern against the proposed links. "India's river-linking project would be an economic, social and ecological disaster", said Mr. Jairam Ramesh, Indian Minister for Rural Development, Drinking Water and Sanitation. "Large-scale interlinking of rivers, which is the vision of some romantic engineers, is ecologically and even from the economic point of view quite a nightmare", Mr. Ramesh said in an exclusive interview with The Daily Star (Karim 2012).

Mr. Som Pal, a former Minister of Agriculture and Water Resources, has argued: "The assumption that there is surplus water available for transfer to other basins is not correct. Most of the river basins of India are deficit ones. It may be argued that the flood waters during the monsoon can be transferred to deficit areas. But most of the existing dam reservoirs seldom get filled to cater to the given requirements of irrigation and power generation. The flooded rivers also carry a huge load of silt, which is likely to choke the channels (D'Monte 2012)."

\section{Reactions from the Neighbors}

Water transfer in the Himalayan component needs to consider the effects on the neighboring countries such as Nepal, Bangladesh and Bhutan. Bangladesh will be a downstream country regarding transfer from the Brahmaputra river. Bangaladesh strongly objects to transferring the Brahmaputra water to the Ganges. India - Bangaladesh Treaty of Dec. 1996, sharing of Ganges waters, India has undertaken to protect the flows arriving at Faraka, which is the sharing point. High dams with storages need to be constructed in Nepal and Bhutan. The neighboring countries have not been informed by India on the proposed NRLP. Not only there is the question of neighboring countries, there will be strong objections from within the country say, Bihar and West 
Bengal and other southern Indian states. The plan needs to be beneficial for all stakeholders.

In the Himalayan links, excepting the Brahmaputra and other rivers in the flood seasons, there are no surplus flows in the rivers. The rivers flowing from Nepal contribute $40 \%$ of the mean annual flow and $70 \%$ of the dry season discharge to the River Ganges. This river basin, now home to nearly 600 million people, is one of the poorest regions in the world. Trans-boundary problems of water pollution, water sharing, and flooding and river channel changes affect all three countries, viz, Nepal, Bangladesh and India.

In the absence of political altruism, and if India unilaterally diverts water to her peninsular basins, Bangladesh would incur huge environmental losses. (Bhaduri and Barbier).

Storage projects within Nepal will highly complement lean season flows and assist the NRLP to achieve its goal. Regulated flows from the reservoir for hydropower generation also contribute to downstream benefits in terms of irrigation, flood control and even navigational use for the basin people. Despite the obvious potential benefits, the countries involved have not been able to get the benefit due to lack of an equitable framework. Further, storage projects come after a price of inundating fertile land, pristine forests, forced displacement of its habitats of human and other species. Till date India does not seem to be eager on paying the environmental service fees that is the rightful compensation to those affected by the storage projects. To make any meaningful regional cooperation, there needs to be a win-win situation for all the countries involved and also all states within India such as Bihar and West Bengal.

"While we recognise rivers as a trans-boundary issue, there has been no direct dialogue as far as building structures in Bhutan for the project (of India) is concerned," Bhutanese Minister for Agriculture and Forests Pema Gyamtsho told the BBC. Bhutan says it has not been appraised of the project idea (Khadka 2012).

Senior Nepalese water expert Santa B. Pun said, "There were concerns that politicians might not be able to secure a good deal for allowing India to build dams and reservoirs in Nepalese territory. That is because we hear our leaders talking only about the stereotype hydropower development; whereas they should be focusing on making India pay for the downstream benefits it would be getting from its river-linking infrastructures in Nepal. "Such concerns also stem from the fact that some think Nepalese politicians are too preoccupied with the prolonged peace process that India mediated after a 10-year Maoist insurgency (Khadka 2012).

Media reports and academic papers apart, little has come out officially about the inter-river linking project. Indian water resources ministry officials made no comment to the BBC's query on how India took its neighbors' reactions to the recent Supreme Court's order to implement the river linking project. Many of India's past water treaties and agreements with neighboring countries Bangladesh, Nepal and Pakistan have been mired in disputes (Khadka 2012).

\section{Indian Strategy in Water Resources Development Areas close to the International Border}

It is an established principle that trans-boundary countries honor international practice and norms in utilizing international rivers. To the contrary, the water resources development in South Asian region, especially in Indian states have been managed or developed with the diversion structures in the international rivers preemptively without any consultation with the riparian countries and, later on, forced the concerned riparian countries to come to negotiation. The following examples could be taken as the illustration:

- India unilaterally stopped water supply to Pakistan through Indus River in 1948;

- India constructed the Farakka Barrage without consultation with Bangladesh, the then East Pakistan.

- The Tanakpur Barrage was completed in 1988 on the Mahakali River, a river bordering Nepal and India. The Mahakali Integrated Treaty was forced on Nepal to be concluded in 1996 after the operation of the barrage was not feasible unless an afflux bund were connected onto the highland in the Nepal side;

- Again, India constructed the Laxmanpur Barrage in the Indian side of the Rapti River. The afflux so formed has been inundating human settlements and thousands of hectares of fertile land in Nepal.

\section{Regional Cooperation}

The cooperation of regional river basin partners is essential for the successful development of shared water resources to its full potential. Previous experiences with the regional/bilateral cooperation in water sharing indicate the need for more confident approach to eliminate the anomalities and in equity sharing. Little or almost no progress in this field would be achieved until the partner countries involved develop a better philosophy and framework of cooperation. To be successful, all riparian countries must accept that a nation's right to an equitable share of its own water resources is fundamental. Despite the obvious potential benefits, the basin countries have not been able to get the benefit due to lack of such a framework.

Mutual interest on increasing net benefits through development of projects are normally a prerequisite for cooperation. Benefits from water resources in this region are likely to be realized only by a well coordinated approach. Shared water resources present opportunities as well as problems.

If so, how should we deal with our conflicts over Water Resources?

"Come together, speak in concord, let your minds comprehend alike, let our efforts be united, let our hearts be in agreement, let our minds be united so that we all live in peace" - Riga Veda. 


\section{Conclusion}

The proposed NRLIP, if completed, will be the biggest water transfer project in the world. It will have financial, social and environmental implications and repercussions on a gigantic scale. The proposal seems to be a conceptual one at present. As shown by the IWMICPWF's three years strategic analysis, there are many factors not considered, or the factors considered are not relevant and realistic. There is no debate that India needs increased water supply, especially to counter the effects of climate change.

Very detailed analyses need to be done including possible alternatives to the project. A win win situation needs to be formulated to gain the confidence of the neighboring countries such as Bangladesh, Bhutan and Nepal.

\section{Acknowledgements}

This paper is mostly based on the findings from the CPWF Project Report: Strategic Analysis of India's River Linking Project (SAIRLP). Project Number PN 48, which is itself a summary of the various reports published under IWMI-CPWF study on SAIRLP which is duly acknowledged.

Naveen Mangal Joshi, B. Sc. (Civil), M.Sc. (Water resources, Roorkee, India) is a Water Resource Engineer with 33 years of experiences in irrigation planning, design, and construction management. As a Project Manager in the Water \& Energy Commission Secretariat (WECS), he was instrumental in preparing the Water Plan of Nepal. For the last 28 years, he served in the Department of Irrigation of Nepal Government, and in his later years he was Project Director in the Community Managed Irrigated Agriculture Sector Project (CMIASP) supported by the ADB. He is experienced in Dispute Resolution works and is listed as Panel Member/Arbitrator in the Nepal Arbitration Council. Currently, he is a free lancer in water resources, contract management and arbitration.

Corresponding Address: namanjos@hotmail.com

\section{Bibliography}

Amarshinge, Upali, 2009 CPWF Project Report, Strategic Analysis of India's River Linking Project, Project No.
PN 48.

Amarshinge, Upali, T. S. Amarsinghe, R.P.S. Malik, 20082009, IWMI "Strategic Analyses of the National River Linking Project of India" by "Standing Committee of Water Resources (2008-09) - Interlinking of Rivers" Eleventh Report.

Bhadra, Binayak, Water Resources Development and Management: Institutional and Legal Issues in a Regional Context.

Darryl, D'Monte, 2012, Linking Rivers: Tragedy of Errors, Enfochange News and Features, 3 Dec. 2012.

Gautam, Upendra and Sachin Upadhyay, 2003, Up In the Stream: The Melting Himalayan, Biogas and Natural Resources Management Nepal (Newsletter) Consolidated Management Services Nepal, Kathmandu, 2003.

Karim, Rezaul, 2012 River Linking Project 'quite a nightmare', The Dalily Star, Aug 6, 2012.

Khadka, Navin Singh, 2012, Environment reporter, BBC News, Concerns over India rivers order, 30 March 2012; http://www.bbc.co.uk/news/scienceenvironment-17555918

Legal Issues related to Nepal's Use of International Watercourse, Report No. Tech./100397/1/1 Seq. No. 005- Water and Energy Commission Secretariat (WECS), Kathmandu.

Nepal International Water Resources and International Law, Report No. 6/4/280696/1/1 Seq. No. 492- Water and Energy Commission Secretariat, Kathmandu.

Shah, T., U. A. Amarsinghe and P.G. McCornick, 2008, India's River Linking Project - The State of Debate. In "National River Linking Project- Analysis of Hydrological, Social and Ecological Issues". Strategic Analysis of National River Linking Project of India. Series 2. Eds. Baharati R Sharma and Upali A Amarsinghe, Colombo, Sri Lanka: International Water management Institute.

Shankari, Uma (Compiled and edited by); "Interlinking Rivers - Contradictions and Confrontations".

Toufiq, A.S., Siddiqi and Shirin Tahir-Kheli, 2004, Water Conflicts in South Asia: Managing Water Resource Disputes within and between Countries of the Region; Published by: Honolulu: Global Environment and Energy in the 21st Century.

\section{CALENDAR OF EVENTS - WATER AND WASTEWATER}

5-6 March, 2013: International Research Conference on Environmental Issue and Waste Management (IRCEIWM). Location: Bangkok, Thailand. More info:http://allinternationalconferences.com/ bangkok2013march/index.html

6-8 March, 2013: $5^{\text {th }}$ Canadian Wastewater Management Conference and 48th Central Canadian Sympoasium on Water Quality Research. Location: Sheraton Hamilton, Hamilton, Ontario. More info: http://www.cwwa.ca/ wastewaterconference_e.asp

15-26 April, 2013: Waste Management Course for
Pacific Islanders. Location: Suva, Fiji. More info: http://www.sidsnet.org/events/waste-managementcourse-pacific-islanders

29-31 May, 2013: Save the PLANET: 4th Conference and Exhibition on Waste Management, Recycling, Environment for South-East Europe. Location: Sofia, Bulgaria. More info: http://www.eco.viaexpo.com/ en/conference

27-28 June 2013: IWA Regional Conference on Waste and Wastewater Management, Science and Technology. Location: Limassol, Cyprus. More info: www.wwmst.org 